Journal of Scientific Perspectives

Volume 3, Issue 2, Year 2019, pp. 133-140

E - ISSN: 2587-3008

URL: http://ratingacademy.com.tr/ojs/index.php/jsp

DOI: https://doi.org/10.26900/jsp.3.014

Research Article

\title{
USING FIRED WALL TILE'S SCRAPS IN FLOOR TILE BODY
}

\author{
Savaş ELMAS* \\ * Res. Assist., Çanakkale Onsekiz Mart University, Faculty of Fine Arts, Ceramic and Glass \\ Department, Çanakkale,TURKEY, E-mail: savaselmas@comu.edu.tr \\ ORCID ID: https://orcid.org/0000-0003-2913-0303
}

Received: 3 March 2019; Accepted: 29 April 2019

\begin{abstract}
The effect of the addition of the fired wall tile's scraps in floor tile body was studied. The fired wall tile's scraps were added to floor tile body according to 1.96-5.66-10.71-17.85 wt. \% ratios. The sintering behavior of the floor tile was evaluated by measuring the water absorption, fired shrinkage, dry shrinkage and fired strength. In addition, microstructure and phase analysis were investigated by scanning electron microscopy (SEM), energy dispersive $x$-ray (EDX) and $x$-ray analysis (XRD). Firing was carried out at 1189 OC for $40 \mathrm{~min}$. in industrial type continuous kiln. It is seen that the addition of $5.66 \mathrm{wt}$ \% of the wall tile's scrap to the floor tile increases the fired strength value. In the XRD analysis, anorthite phase was observed which shows fired strength and chemical resistance.
\end{abstract}

Keywords: Fired scraps wall tiles, Floor tiles, Environment savings, Cost of product

\section{INTRODUCTION}

The use of waste in ceramic structures is important due to the protection of the existing raw material, the prevention of the harmful effects to the environment by evaluating the waste material and the price advantage according to the material it will take instead. According to Karamanov and al. [1], with using fired porcelain scraps at $15 \mathrm{wt} . \%$ in hard porcelain body, quartz dissolution increase that increase liquid phase content, was determined. The effects of firing at $1300-1350{ }^{\circ} \mathrm{C}$, improved sintering and mechanical characteristics were determined. In an analysis of Nodeh [2], firing temperature and linear expansion decreased as a result of adding the bone chine porcelain waste to the hard porcelain body. On the other hand, the glassy phase, probability of deformation and total shrinkage increased. The addition of $6 \mathrm{wt}$.\% bone porcelain doubled the fired mechanical strength at $1340{ }^{\circ} \mathrm{C}$. In a study of Torres at al. [3] the granite fired scraps were added to the porcelain body, it was observed that the additions had no effect on density, shrinkage and plasticity. This study revealed that the recipe containing $25 \mathrm{wt} . \%$ granite cutting waste additions imparted superior properties (water absorption $0.07 \%$, bending strength $>50 \mathrm{MPa}$ ) to the porcelain tile structure. Juinora et al. [4] points out that fritted waste and soda lime glass using in glazed and unglazed porcelain tiles, water absorption value has decreased and stain retention resistance has increased. In a study conducted by Martini at al.[5], a high 
percentage (43.62\%) of glass waste-granite-scraps of sanitaryware waste was added to sanitary ware. It was observed that there was no rheological problem. According to a study by Luz[6], the addition of $5 \%$ glass replace feldspar to the porcelain body provides standard porcelain values. In another study by Matteuci at al[7], soda-lime glass was added to the porcelain body up to $10 \%$. It was observed that firing shrinkage and closed porosity increased. Open porosity and bulk density decreased. The use of $0-5 \%$ was found to be appropriate.

The aim of this study is to reduce the cost by using re-use of wall tile's scraps in floor tiles also to reduce environmental wastes.

\section{EXPERIMENTAL PROCEDURE}

The raw materials were prepared from Etili Seramik A.Ş (Çanakkale). Analysis of raw materials are given in Table 1. The samples are ground to degree of $1.55 \%>63$ microns with alumina ball media in $2 \mathrm{~kg}$ laboratory type mills according to composition of Table 2 . The density of slurry was measured $1650 \mathrm{gr} / 1$. After drying at $110^{\circ} \mathrm{C}$ for 1 day in dryers, granules were moistened with 5-6\% and pressed by laboratory presses with $350 \mathrm{~kg} / \mathrm{cm}^{2}$ pressure in size $7 \times 210 \times 100 \mathrm{~mm}$. They were fired in continous type industrial kiln at $1189^{\circ} \mathrm{C}$ in a $40 \mathrm{~min}$.

Table 1. Chemical analysis of raw materials (wt.\%)

\begin{tabular}{|l|c|c|c|c|c|c|c|c|c|}
\hline $\begin{array}{l}\text { Raw } \\
\text { Materials }\end{array}$ & $\mathrm{SiO}_{2}$ & $\mathrm{Al}_{2} \mathrm{O}_{3}$ & $\mathrm{Fe}_{2} \mathrm{O}_{3}$ & $\mathrm{TiO}_{2}$ & $\mathrm{CaO}$ & $\mathrm{MgO}$ & $\mathrm{Na}_{2} \mathrm{O}$ & $\mathrm{K}_{2} \mathrm{O}$ & L.I. \\
\hline Clay & 54 & 31,8 & 0,67 & 1,17 & 0,3 & 0,45 & 0,13 & 2,03 & 10,05 \\
\hline Kaolen & 51 & 34 & 0,75 & 0,25 & 0,20 & 0,25 & 0,15 & 1,20 & 12 \\
\hline $\begin{array}{l}\text { Na- } \\
\text { Feldspar }\end{array}$ & 68,62 & 19,53 & 0,016 & 0,042 & 0,99 & 0,10 & 10,29 & 0,21 & 0,14 \\
\hline Quarz & 99,35 & 0,12 & 0,06 & 0,01 & 0,05 & 0,05 & 0,05 & 0,06 & 0,2 \\
\hline
\end{tabular}

L.I: Loss of ignition

Table 2. Mixture compositions ( wt.)

\begin{tabular}{|l|l|l|l|l|}
\hline Raw Materials & 1 & 2 & 3 & 4 \\
\hline Kaolen & 25 & 25 & 25 & 25 \\
\hline Clay & 40 & 40 & 40 & 40 \\
\hline Na- Feldspar & 30 & 30 & 30 & 30 \\
\hline Quarz & 5 & 5 & 5 & 5 \\
\hline Fired scraps of wall tiles & 0 & 2 & 6 & 12 \\
\hline
\end{tabular}
wt: weight

\section{RESULTS}

\subsection{Physical properties}

Phyiscal properties are considered for industrial products according to standards TS EN 14411. Table 3. shows the slip viscosity, fired loss, fired shrinkage, dry strength and fired strength values of all recipes. As seen in Figure 1, the viscosity increase is observed in the slip with the increase fired scraps of wall tile in floor tile. As seen in the graph in Figure 2, firing shrinkage value decreases to $5.66 \%$ of wall tile's scraps and then increases. When the change in the dried and fired strength value with the added fired wall fracture scraps was examined, 
until the addition value of $5.66 \%$, both of them values is seen to increased then decreased. The reason why dry strength falls after a certain value is that this material is not plastic. Anortite phase is seen in the sample containing 5.66\% waste. According to Gdula [8], Ismail and al.[9], Pozutak at al. [10], it is stated that the amount of anorthite in the structure has a strength increasing effect [11]. At the same time, the reduction in the firing shrinkage is thought to be due to the anorthite crystal.

Table 3. Physical features of fired floor tiles samples

\begin{tabular}{|l|l|l|l|l|}
\hline & 1 & 2 & 3 & 4 \\
\hline Slip viscosity $(\mathrm{sn})$ & 33 & 33 & 35 & 37 \\
\hline Loss of ignition (\%) & 3,49 & 3,59 & 3,47 & 3,39 \\
\hline Fired shrinkage (\%) & 9.07 & 8,84 & 8.96 & 9.46 \\
\hline Water absorbtion (\%) & 0,008 & 0,016 & 0,016 & 0,007 \\
\hline Dried strength $\left(\mathrm{kg} / \mathrm{cm}^{2}\right)$ & 16,78 & 18,35 & 18.68 & 16.26 \\
\hline Fired strength $\left(\mathrm{kg} / \mathrm{cm}^{2}\right)$ & 458.45 & 472.89 & 488.02 & 431.49 \\
\hline
\end{tabular}

Figure 1. Viscosity - fired scraps of wall tiles wt. \% changes

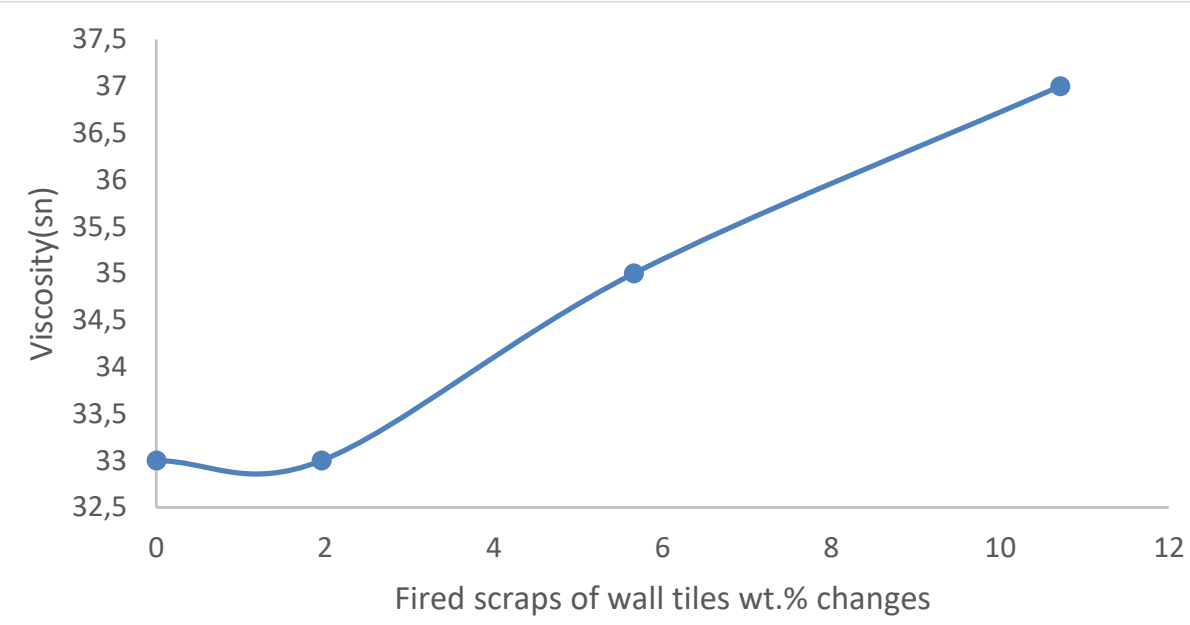

Figure 2. Fired shrinkage - fired scraps of wall tiles wt. \% changes

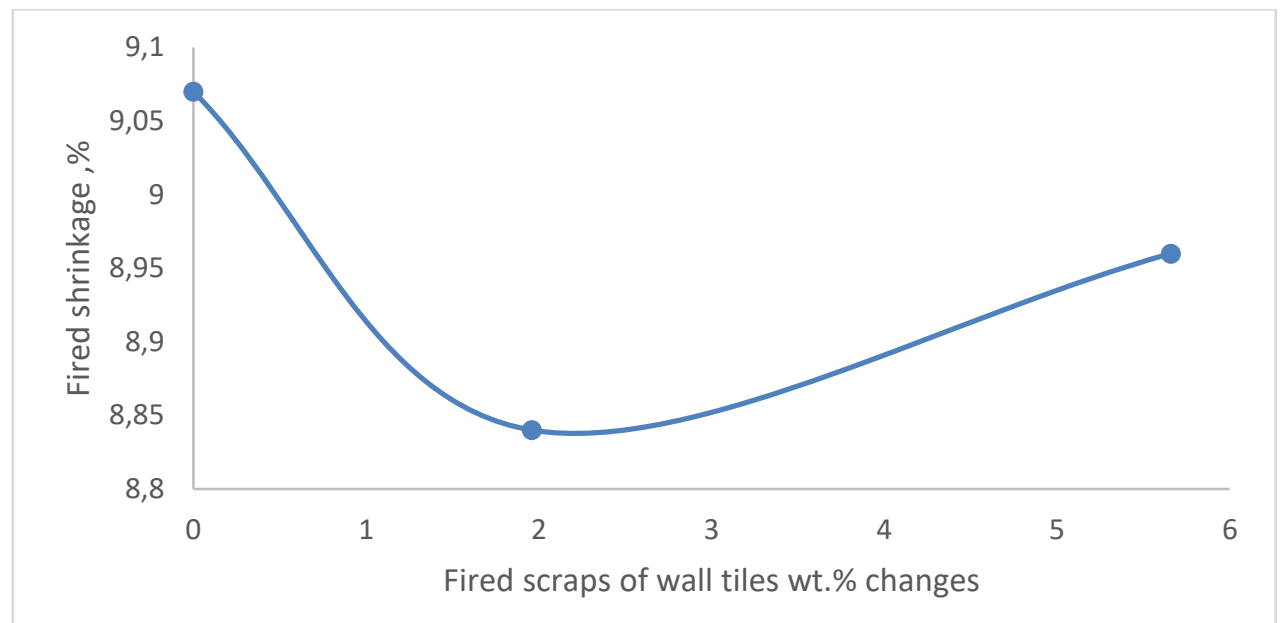


Figure 3. Fired strength- fired scraps of wall tiles wt. \% changes

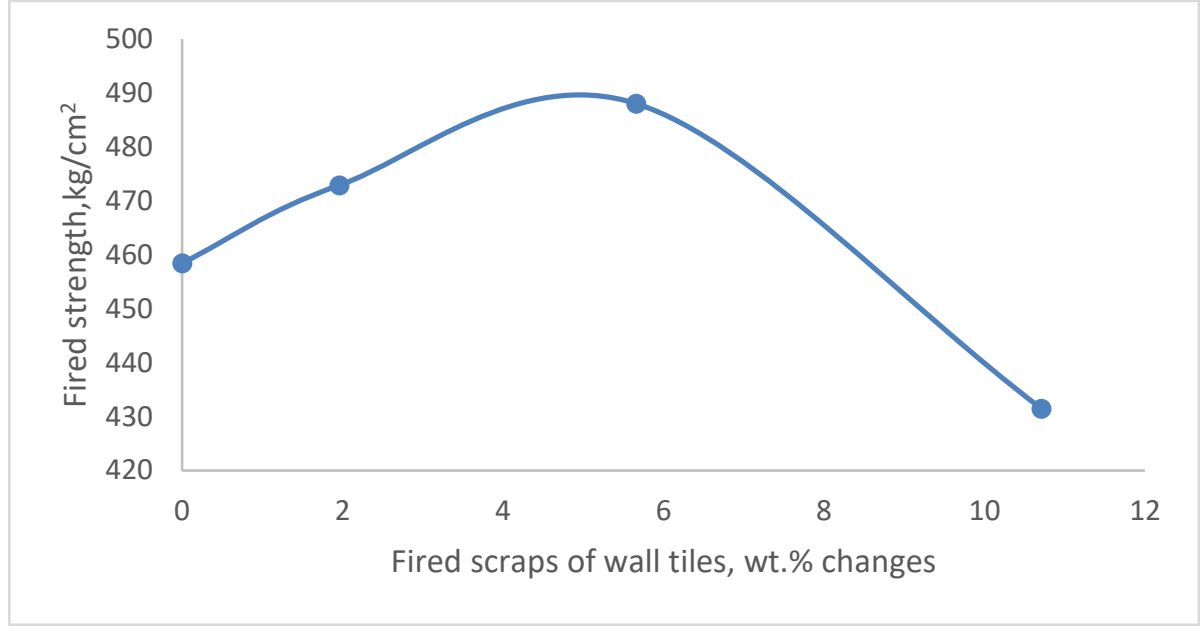

Figure 4. Water absorbtion- fired scraps of wall tiles wt. \% changes

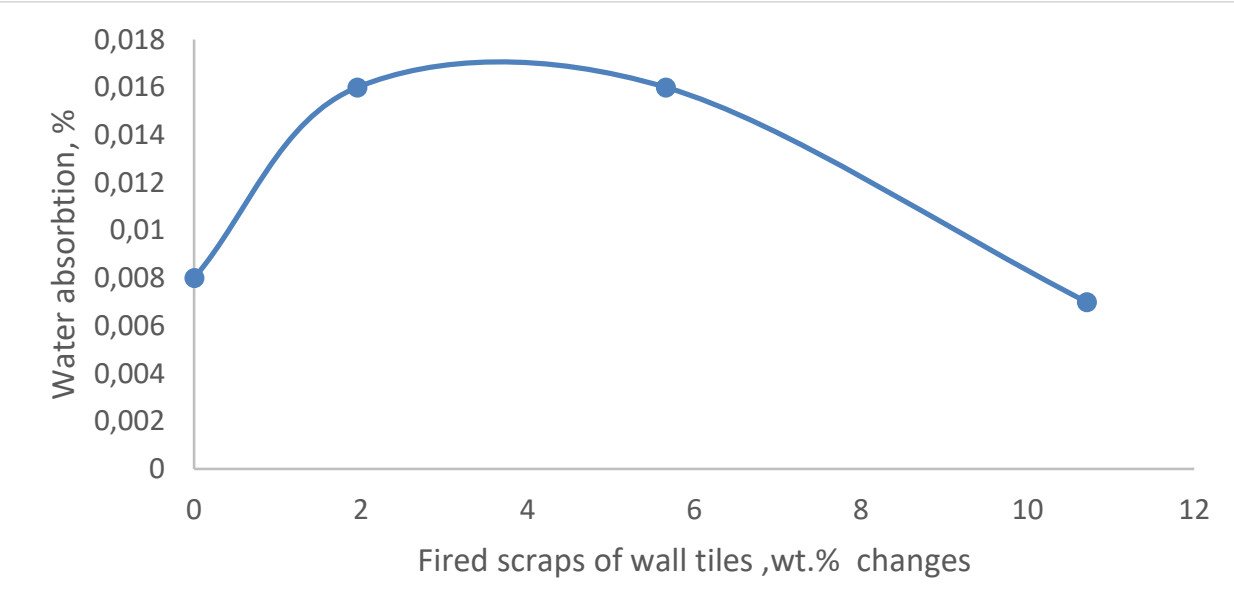

Figure 5. Dried strength- fired scraps of wall tiles wt. \% changes

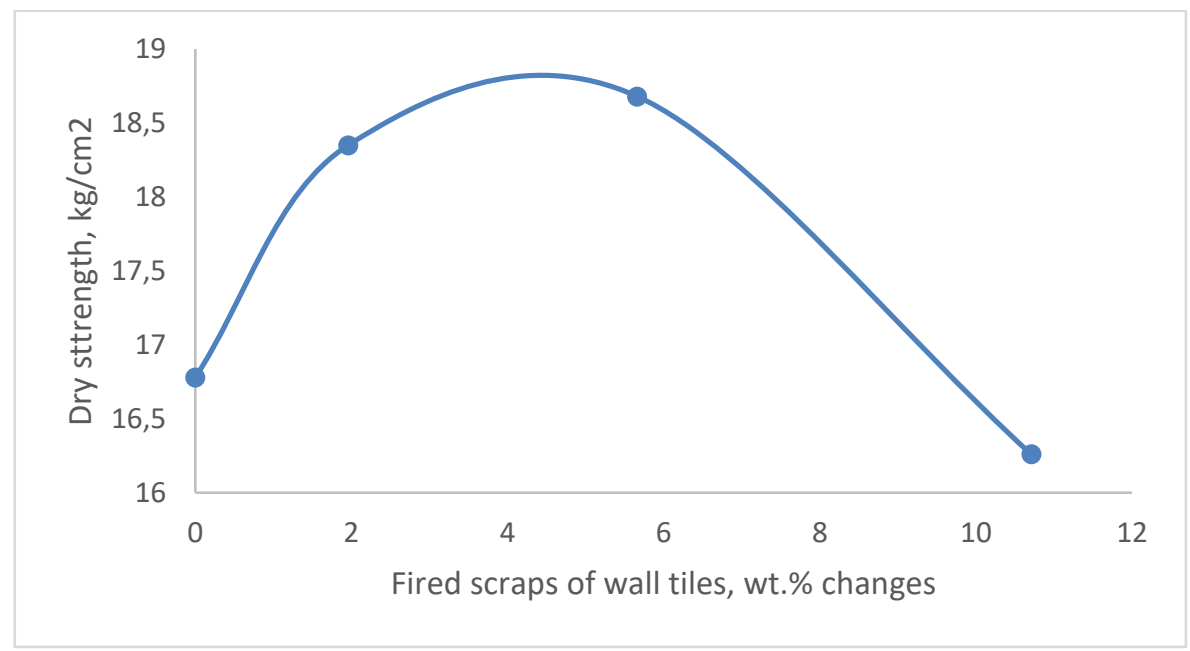




\subsection{Microstructure and phase analysis of the body}

The phases formed in the samples 1 and 3 were determined from the corresponding XRD patterns are shown in Figure 6. Quartz, mullite, albite and cristobalite were found in standard floor tiles, while quartz, mullite, anorthite and calcium rich albite were found in the floor tile containing $5.66 \%$ of fired wall tiles. It is thought that the decrease in the quartz owing to low level of liquid phase viscosity and/or increases of quantity of liquid phase . Although mullite peaks are similar in both structures, anorthite phase is observed in composition number 3. Kara at all.[12] published an article related to floor tiles which was contain XRD graphs include quartz,albite and mullite peaks in fired tile. Floor tile with added fired wall tile scraps contains quartz, mullite, anorthite and albite phase.

Figure 6. XRD patterns of 1 and 3

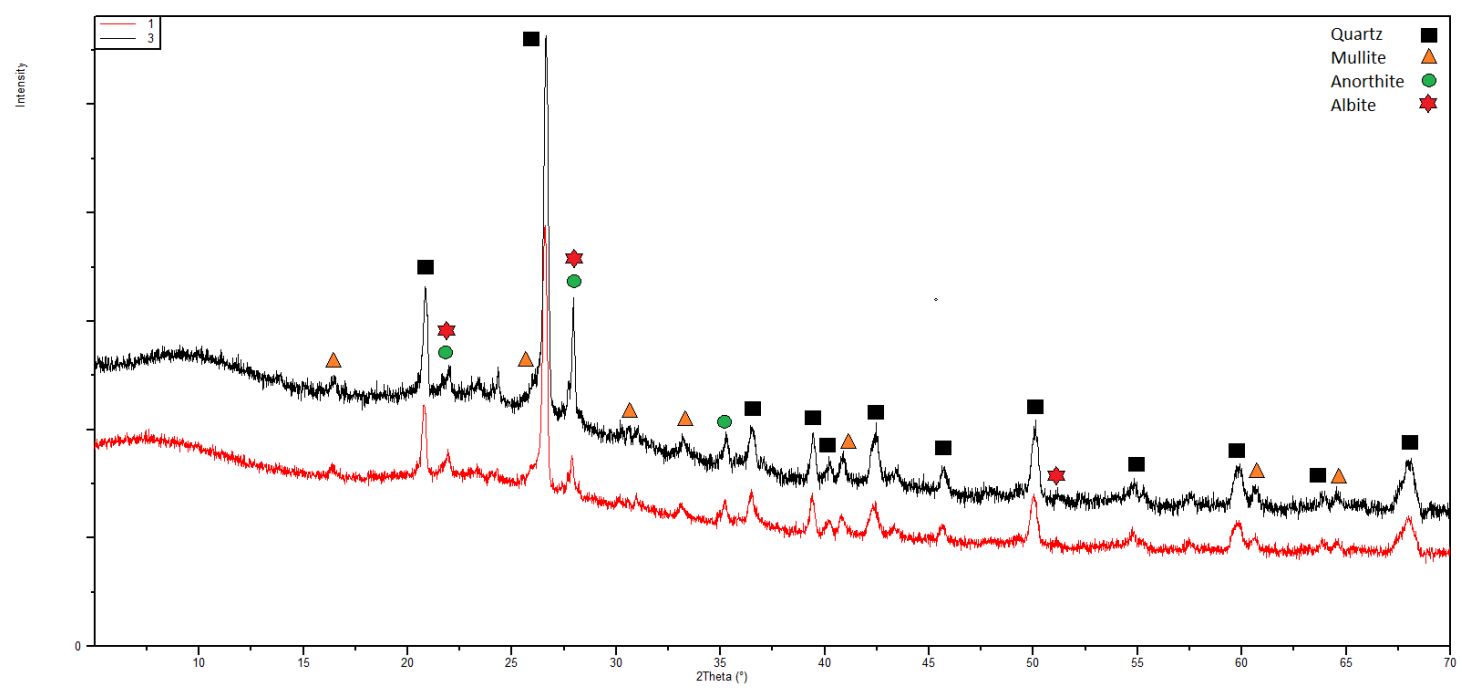

The scanning electron microscope (SEM) images of the standard composition (1) and the highest fired strength sample (3) are shown in Figure 7. Free quartz particle can be seen in 1. At the 1 and 3 composition, it is observed the high sintering with glassy phase. The low homogeneity of mixing process's can lead pore or crack occurence in 1 . On the other hand, the composition 3 shows a continuous and much more glassy structure. The increase in sintering provides a decrease in water absorption and an increase in fired strength in the no 3 composition. 
Figure 7 a) $100 \mathrm{X}$ magnified image of standard (number 1) composition

b) $100 \mathrm{X}$ magnified image of 3 number composition

c) $2000 \mathrm{X}$ magnified image of standard (number 1) composition

d) $2000 \mathrm{X}$ magnified image of 3 number composition

a) 1 no sample

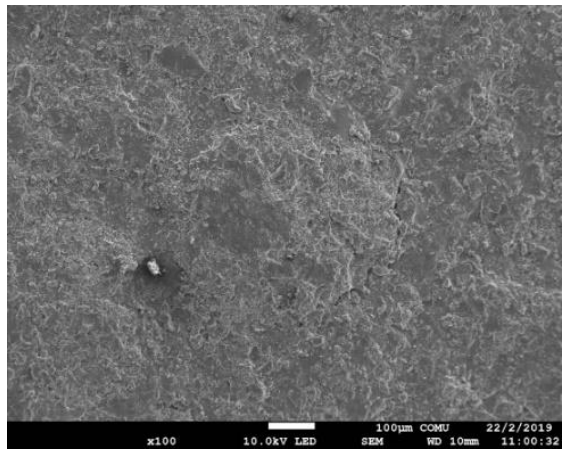

c) 1 no sample

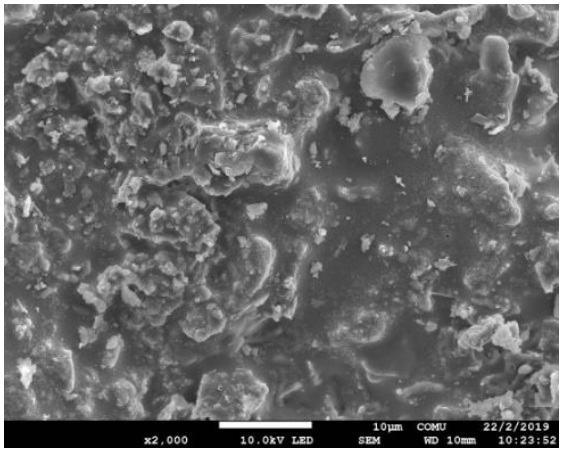

b) 3 no sample

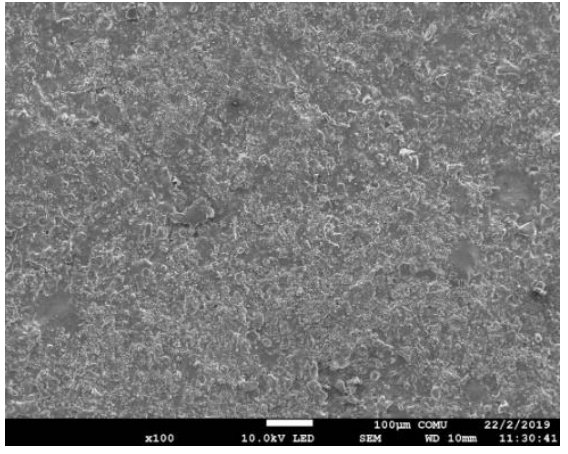

d) 3 no sample

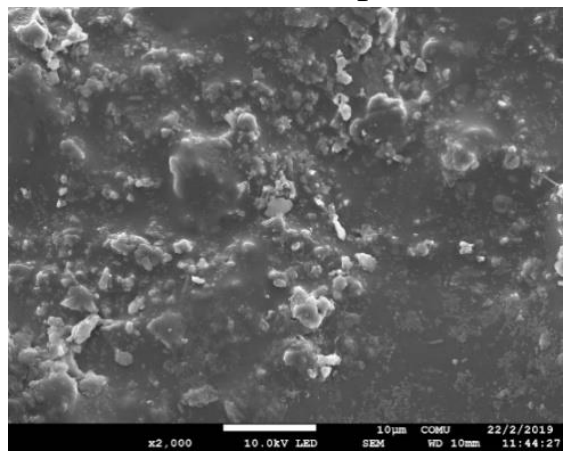

The energy scattering x-ray (EDS) of the recipe 1 and 3 are shown in Figure 8. A high sintering is observed in both structures; The glassy phase is dominant in the ceramic structure. In the composition 3, the amount of $\mathrm{Ca}$ is higher than the other, as can be seen from the EDS spectrum. In addition, the reason of other differences of the EDS is nature of raw material and process conditions.

Figure 8. a) EDS analysis of recipe 1

b) EDS analysis of recipe 3

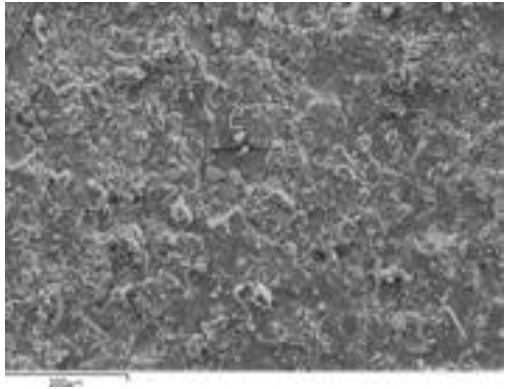

a) 1 no sample

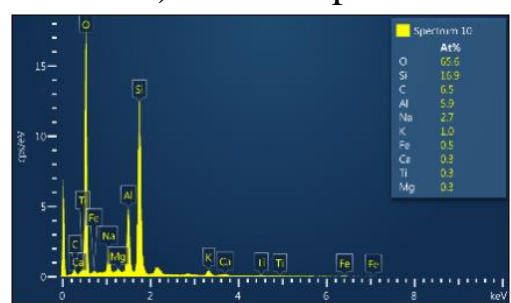

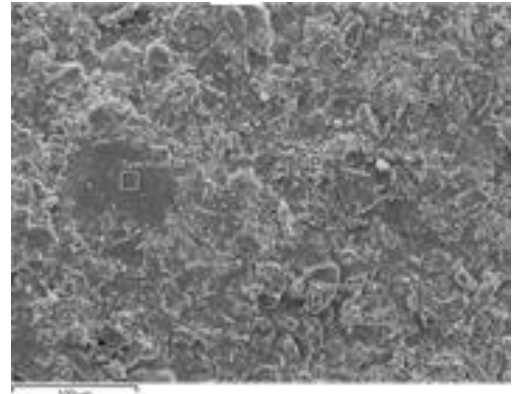

b) 3 no sample

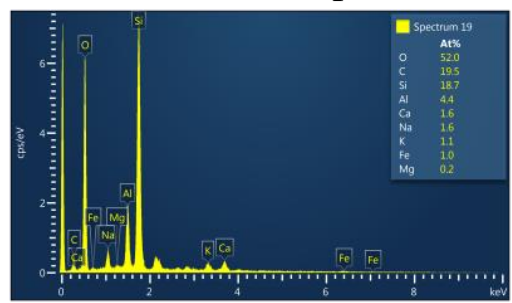




\section{CONCLUSIONS}

In order to prevent environmental pollution and to reduce the cost of ceramic tiles, it was determined that the wall tile waste could be used up to $5.66 \%$ in the floor tile. Thus, a floor tile structure was obtained in which similar water absorption and fired shrinkage were obtained with high fired strength value. With this amount of adding of scraps, sintering and mechanical properties were improved. In future studies on the subject, the use of fired wall tile waste in floor tiles instead of quartz component can be investigated. 


\section{REFERENCES}

[1] KARAMANOV, A., KARAMANOVA, E., FERRARI, A.M., FERRANTE, F., PELINO, M.,2006, The Effects of Fired Scrap Addition on The Sintering Behaviour of Hard Porcelain. Ceramics International, 32, 727-732.

[2] NODEH, A.A., 2017, Influence of Bone Porcelain Scraps on The Physical Characterictics and Phase Composition of a Hard Porcelain Body. Ceramica y Vidrio, 56. 113-118, Spain.

[3] TORRES, P., FERNANDES, H.R., AGATHOPOUlOS, S., TUlyAGANOV, D.U., FERREIRA J.M.F., 2004, Incorporation of Granite Cutting Sludge in Industrial Porcelain Tile Formulations, Journal of The European Ceramic Society, 24. 3177-3185.

[4] JOUNIORA, A.N., HOTZA, D., SOLER, C.V., VILCHES, E.S., 2010, Influence of Composition on Mechanical Behaviour of Porcelain Tile.Part II: Mechanical Properties and Microscopic Residual Stress, Material Science and Engineering, A 527, 1736-1743.

[5] MARTINI, E., FORTUNA, D., FORTUNA, A., RUBINO, G., TAGLIAFERRI, V., 2017, Sanitser, an innovative sanitary ware body, formulated with waste glass and recycled materials, Ceramica, 63, 542-548

[6] LUZ A.P., RİBIERO S., Use of glass waste as a raw material in porcelain stoneware tile mixtures,2007, Ceramics International 33, 761-765

[7] MATTEUCI, F., DONDI, M., GUARINI, G., 2002, Effects of Soda-Lime Glass on Sintering and Technogical Properties of Porcelain Stoeware Tiles, Ceramics International, 28(8) 878-880.

[8] GDULA, R.A., 1971, Anorthite ceramic dielectric. Am. Ceram. Soc. Bull., 50(6).555-557.

[9] ISMAİL, M.G.M.U., ARAI, H., 1992, Sol-gel Synthesis of $\mathrm{B}_{2} \mathrm{O}_{3}$-doped Anorthite and its Characteristics. J. Ceram. Soc. Jpn., 100(12) 1385-1389

[10] POZUTAK, M., SOLVANG, M., DINGWELL, D., 2006, Temperature independent thermal expansivities of calcium aluminosilicates melts between 1150 and $1973 \mathrm{~K}$ in the system anorthite- wollastonite-gehlenit: a density model., Geochim Cosmochim Acta, 70. 3059-3074.

[11] KURAMA, S., OZEL, E., 2008, The Influence of different $\mathrm{CaO}$ source in the Production of Anorthite Ceramics. Ceramics International, 35. 827-830.

[12] KARA, A., ÖZER, F., KAYACI, K., ÖZER, P., 2006, Development of a multipurpose tile body: Phase and microstructural development, 26. 3769-3782. 